\section{Socio Economic Impact Due to Climate Variability on Selected Villages of Ukhrul and Thoubal Districts, Manipur}

\section{Sanamacha Meetei ${ }^{\star}$, Mohd Habibullah Khan, Ashem Rahul Singh, SW Yuingamla, Zahir Shah and Onil Laishram}

Directorate of Environment and Climate Change, Porompat, Imphal East, Manipur, India

\begin{abstract}
As global climate change continues, many of the villages are likely to become vulnerable at present. The altering of spring shed cycles, rainfall pattern, evaporation, precipitation and temperature are all subjected to climate variability and change. The present paper defined to study the socio-economic impacts due to climate variability on certain villages of Ukhrul and Thoubal districts, Manipur. Tentha and Khekman village are selected from Thoubal district where as Shirui and Hungpung village are selected from the Ukhrul district based on their vulnerable status. Socio economic and livelihoods status were conducted with the structured questionnaire interview and informal discussions. Questionnaire system was used to get responses in a standardized and cost-effective way. The one-way forward option is to reduce the socio-economic vulnerability and improve the ecological systems and services.
\end{abstract}

Keywords: Climate; Manipur; Socio economic; Selected; Villages; Vulnerable

\section{Introduction}

Directly or indirectly, global climate change is associated with the socio-economic and environmental impacts. Houghton [1], welldefined the impact of climate change on human society as well. More studies reveal that the impact of climate change depend on certain factors like demography, occupations, earnings, literacy, poverty

${ }^{*}$ Corresponding author: Sanamacha Meetei, Directorate of Environment and Climate Change, Porompat, Imphal East, 795005, Manipur, India, Email: sanamacha4@gmail.com

Citation: Meetei S, Khan MH, Singh AR, yuingamla SW, Shah Z, et al. (2021) Socio Economic Impacts of Climate Variability and Change on Selected Villages of Ukhrul and Thoubal Districts, Manipur. J Environ Sci Curr Res 4: 027.

Received: March 24, 2021; Accepted: April 19, 2021; Published: April 26, 2021

Copyright: ๑) 2021 Meetei S, et al. This is an open-access article distributed under the terms of the Creative Commons Attribution License, which permits unrestricted use, distribution, and reproduction in any medium, provided the original author and source are credited. incidence and dependency on government funds. In such cases, rural communities tend to be more vulnerable in comparison to urban counterparts. Therefore, the need of time is to delineate climate change impacts across rural and urban communities, and to develop appropriate policies to mitigate or adapt the impacts. Public awareness and capacity building will enhance more on understanding the present scenario of climate change. Moreover, facilitate assessment of climate change vulnerabilities and risk on bio-physical and socio-economy in terms of water, agriculture, forest and health sectors geared towards reducing climatic vulnerability is warranted. According to Hewitt [2], social vulnerability is the susceptibility of a given population to be harmed from exposure to a hazard, directly affecting its ability to prepare for, respond to, and recover. Furthermore, Houghton [1], calculated the temperature increase in the last hundred years and the last three decades have been successively warmer at the Earth's surface than any preceding decade since 1850 IPCC [3], Moreover, climate change impacts on human health could occur through both direct (e.g., thermal stress) and indirect (e.g., disease vectors and infectious agents) pathways. Karl [4], suggested that direct impacts could result from increased exposure to temperature (heat waves, winter cold) and other extreme weather events (floods, cyclones, storm-surges, droughts) and increased production of air pollutants and aeroallergens such as spores and molds.

\section{Materials and Methods}

Both valley and hills formed the State, Manipur. According to the Forest Survey of India FSI [5], report, the state lies between Latitude of $23^{\circ} 83^{\prime} \mathrm{N}-25^{\circ} 68^{\prime} \mathrm{N}$ and a Longitude of $93^{\circ} 03^{\prime} \mathrm{E}-94^{\circ} 78^{\prime} \mathrm{E}$. The total area covered by the State is $22,327 \mathrm{sq}$. kms. Due to its different topographical location, terrain diversity, altitudinal variation and river system, the state experiences diverse climate variability especially in terms of ecosystem, biodiversity and livelihood, agriculture \& its allied, water resources, forest, health, etc. It is therefore necessary to pay attention to climate disaster and other geo physical parameters in order to secure the future environment and also to help state build resilience for these dramatic climate and weather extremes.

Authors prepared structured type questionnaire for defining the village socio economic profile. Interview and informal discussions were conducted to overcome the poor response rates of a normal questionnaire survey. Moreover, personal interview of local youth, women's and leaders of the village community of varying ages, sexes and economic background to ensure clarity and effectiveness of the questions before use. Respondents were selected from different sex, age group, educational, social and economic classes. Secondary data were obtained from the office file, research works and published article etc (Table 1).

\section{Study area}

Thoubal district (Khekman and Tentha): The villages (Khekman and Tentha) experienced three-times floods during last year 
Citation: Meetei S, Khan MH, Singh AR, yuingamla SW, Shah Z, et al. (2021) Socio Economic Impacts of Climate Variability and Change on Selected Villages of Ukhrul and Thoubal Districts, Manipur. J Environ Sci Curr Res 4: 027.

inundating many of the agricultural fields losing different varieties of crop species. The local describe drought like situation after the floods. The worse condition is the reduction of rice production in the defined villages after post floods (Table 2).

Ukhrul district (Hungpung and Shirui): The villages (Shirui and Hungpung) reflect floods and landslides on regular interval of time. At recent times, the villages receive heavy rainfall during the pre-monsoon season causing landslides. Moreover, the destruction and degradation of surrounding forests led to the problem of water scarcity during lean season of the year. In most cases, spring is near to threatened due to the felling of trees for Livelihood purposes. Moreover, erratic rainfall, no rainfall and even heavy rainfall disturbs the agriculture and agricultural practices. The introduction of new insect species is another notable achievement in the selected villages. (Table 3)

\begin{tabular}{|c|c|c|c|c|}
\hline Sample village & Khekman & Tentha & Shirui & Hungpung \\
\hline Total population & 8957 & 10659 & 1085 & 11752 \\
\hline Total household & 1513 & 1890 & 228 & 2609 \\
\hline No. of male & 4578 & 5543 & 572 & 6061 \\
\hline No. of female & 4379 & 5116 & 523 & 5691 \\
\hline Sex ratio & 956.53 & 922.96 & 914.33 & 938.95 \\
\hline Literacy rate & 36.77 & 27.95 & 22.76 & 21.68 \\
\hline
\end{tabular}

Table 1: Demographic profile of the selected villages, Census [6].

\begin{tabular}{|c|c|c|c|}
\hline SL NO & $\begin{array}{c}\text { Name of the } \\
\text { village }\end{array}$ & $\begin{array}{c}\text { Total population } \\
\text { (2011 census) }\end{array}$ & $\begin{array}{c}\text { Number of house } \\
\text { hold (2011 census) }\end{array}$ \\
\hline 1 & Khekman & $\mathbf{7 1 5 7}$ & $\mathbf{1 3 6 9}$ \\
\hline 2 & Tentha & 9087 & 1766 \\
\hline 3 & Hundung & 10785 & 2036 \\
\hline 4 & Shirui & 1265 & 284 \\
\hline
\end{tabular}

Table 2: Population profile of the selected villages.

\begin{tabular}{|c|c|c|c|c|}
\hline Villages & WATER & FOREST & AGRICULTURE & HEALTH \\
\hline Khekman & $\begin{array}{l}\text { Frequent flood due to erratic rainfall with high intensity. } \\
\text { Shifting of rainfall pattern, deficit during monsoon \& high intensity. } \\
\text { Off and on of water source } \\
\text { Decreasing of underground water recharge } \\
\text { Mainly depend on river water. } \\
\text { Drying up of wetlands and reservoirs. }\end{array}$ & $\begin{array}{l}\text { Degradation of } \\
\text { forest cover, } \\
\text { urbanization }\end{array}$ & $\begin{array}{l}\text { Mono crops cultivation practising there by damaging varieties } \\
\text { of field crops due to impact of erratic rainfall. } \\
\text { Shifting of livelihood, outmigration of youths, etc. } \\
\text { Failure of rainfed agriculture, variability of yield. } \\
\text { Limited adaptive capacity of farmers to new varieties of crop. } \\
\text { New disease and pests. }\end{array}$ & $\begin{array}{l}\text { Nutrient deficiency. } \\
\text { Respiratory prob- } \\
\text { lems. } \\
\text { Cardiac problem, } \\
\text { diabetes, BP strokes } \\
\text { problems etc. } \\
\text { Water borne diseases. }\end{array}$ \\
\hline Tentha & $\begin{array}{l}\text { Frequent flood due to erratic rainfall with high intensity. } \\
\text { Shifting of rainfall pattern, deficit during monsoon \& high intensity. } \\
\text { Off and on of water source. } \\
\text { Decreasing of underground } \\
\text { water recharge } \\
\text { Mainly depend on river water. } \\
\text { Drying up of wetlands and reservoirs. }\end{array}$ & $\begin{array}{l}\text { Degradation of } \\
\text { forest cover, } \\
\text { urbanization }\end{array}$ & $\begin{array}{l}\text { Mono crops cultivation practising there by damaging varieties } \\
\text { of field crops due to impact of erratic rainfall. } \\
\text { Shifting of livelihood, outmigration of youths, etc. } \\
\text { Failure of rainfed agriculture, } \\
\text { variability of yield. } \\
\text { Limited adaptive capacity of farmers to new varieties of crop. } \\
\text { New disease and pests. }\end{array}$ & $\begin{array}{l}\text { Nutrient deficiency. } \\
\text { Respiratory prob- } \\
\text { lems. } \\
\text { Cardiac problem, } \\
\text { diabetes, BP strokes } \\
\text { problems etc. } \\
\text { Water borne diseases. }\end{array}$ \\
\hline Hundung & $\begin{array}{l}\text { Very often Landslides due to erratic rainfall with high intensity. } \\
\text { Depletion of water table. } \\
\text { Drying up of spring heads. } \\
\text { Limiting of water source. } \\
\text { Shifting of rainfall pattern, deficit during monsoon \& high intensity. } \\
\text { Drying up of wetlands and reservoirs. }\end{array}$ & $\begin{array}{l}\text { Decreasing/ } \\
\text { diminishing } \\
\text { of forest } \\
\text { resources. } \\
\text { Vulnera- } \\
\text { ble due to } \\
\text { fragmentation, } \\
\text { Degradation, } \\
\text { conservation } \\
\quad \text { etc. }\end{array}$ & $\begin{array}{l}\text { Rich in bio-resources and traditional knowledge for conser- } \\
\text { vation } \\
\text { Limited adaptive capacity of farmers to new varieties of crop. }\end{array}$ & $\begin{array}{l}\text { Nutrient deficiency. } \\
\text { Respiratory prob- } \\
\text { lems. } \\
\text { Cardiac problem, } \\
\text { diabetes, BP strokes } \\
\text { problems etc. } \\
\text { Water borne diseases. }\end{array}$ \\
\hline Shirui & $\begin{array}{l}\text { Very often Landslides due to erratic rainfall with high intensity. } \\
\text { Depletion of water table. } \\
\text { Drying up of spring heads. } \\
\text { Limiting of water source. } \\
\text { Drying up of wetlands and reservoirs. } \\
\text { Shifting of rainfall pattern, deficit during monsoon \& high intensity. }\end{array}$ & $\begin{array}{l}\text { Decreasing } \\
\text { of forest } \\
\text { resources. } \\
\text { Vulnera- } \\
\text { ble due to } \\
\text { fragmentation, } \\
\text { degradation, } \\
\text { conservation } \\
\text { etc. }\end{array}$ & $\begin{array}{l}\text { Rich in bio-resources and traditional knowledge for conser- } \\
\text { vation } \\
\text { Limited adaptive capacity of farmers to new varieties of crop. }\end{array}$ & $\begin{array}{l}\text { Nutrient deficiency. } \\
\text { Respiratory prob- } \\
\text { lems. } \\
\text { Cardiac problem, } \\
\text { diabetes, BP strokes } \\
\text { problems etc. } \\
\text { Water borne diseases. }\end{array}$ \\
\hline
\end{tabular}

Table 3: Vulnerable sectors. 


\section{Results and Discussion}

During the study period from January 2020 to December, 2020, it was difficult time for the authors as the pandemic covid-19 disturbs the whole state of Manipur. It was observed that the authors found that most people in the selected villages (Tentha and Khekman) of Thoubal districts depend on agriculture and agricultural practices for sustaining their livelihood. Irrigation supported horticulture and rearing of small and large livestock are other option for the secondary income. Sometimes, pisci culture works well during peak hour of the year. Out of the 7157 population in Khekman, numbers of farmers identified are 2654, number of governments employed reached to 156, 12 people woks on private sectors, 101 people are living with business and 1382 are unemployed as recorded in the census book, 2011 whereas number of farmers in Tentha village are 1176, 148 people works on government department, 2535 are students, 190 peoples are working under private sectors, 37 are business and 2256 are unemployed. Unfortunately, the scenario of climate variability and change are likely to exaggerate the problems of future food security by exerting pressure on agriculture. The total agricultural land calculated in Khekman is 556 Sangam while 872 Sangam is recorded in Tentha village. More importantly, Ravindranath [7], suggest that agricultural yields are more unstable in rain-fed areas than irrigated ones due to unpredictable climate changes. An estimated 3.5-millionhectare land which has under rain-fed cultivation, accounts for about $30 \%$ of the total area under cultivation. During natural calamities and hazards, the people of Khekman village faced problem like floods and droughts. Over 1368 families are frequently affected by flood and 248 families are rarely affected by drought. The same problem is faced by the Tentha village. Over 1232 families are frequently affected by flood, 150 families on occasional seasons and 137 families are rarely affected by flood. The worst case is post flood, like spreading of disease, non-availability of essential commodities and medicines and loss of dwellings etc. Besides, the villages do not face the problem of drought frequently, but over 264 families of the village faced occasionally and 230 families faced rarely.Health facilities are few and thinly in both the villages. The women in particular bear the burden of looking after the sick that fail to get modern medical attention.

While in Ukhrul (Hundung and Shirui), shifting cultivation is practicing in the villages for their livelihood. In addition, the villages rear livestock for supplement of household economy. Some of the important livestock are cow, chicken, boar, buffalo etc. Out of the 1265 population in Shirui village, 51 people are engaged in government department, 128 people on agriculture and 13 on agricultural activities, 32 as self-employed and number of students stand at 363 . Whereas, out of the 10785 population in Hundung village, $80 \%$ have their own family agricultural land as many of the villagers depend on agriculture for their socio-economic livelihoods. Moreover, women play a vital role in income generating activities. They sell vegetables, fruits, firewood and other products Non Wood Forest Products (NWFP) found in the forest. At present, all come to a halt to the changing scenario of rainfall patterns, as little rainfall, no rainfall and heavy rainfall etc in the hills. More often, people spend little time in agricultural activities than the earlier. The reason is identified as low productivity of paddy cultivation. Many of the springs are dried up during the summer and winter months of the year leading to water scarcity in both the hill villages. According to Pimentel [8], maintaining biological diversity is essential for productive agriculture, and ecologically sustainable agriculture. Butt [9], suggests that it will be good to change to other crops that maintain forest cover and diversity, diversify the agricultural areas implementing more crops, or change the cropping pattern in warm regions shifting toward patterns used in hotter regions. Therefore, Reilly and Schimmelpfennig [10], recommend adaptation as an important component in any policy response to climate change. Furthermore Challinor [11], mentioned that farmers and producers need to have physical, agricultural, economic, and social resources to moderate, or adapt to, the impacts of climate variability. Parry and Carter and Met Office [12,13] defined, for those people depends on agriculture and cultural practices, food security is an issue of major concern, because climate change will affect crop yields and agriculture. On the other, farmers and producers need to identify the way of crop infection and the way forward option to reduce the way of infection (Table 4).

\section{Conclusion}

The study brings out suggestion in order to understand the scenario of climate variability and change in the selected villages. Firstly, the selected villages need to connect with various stakeholders such as farmers, line department officials, scientists, policy makers etc. to understand the present situation in terms of temperature rise, erratic rainfall, etc. Secondly, people depend on agriculture and agricultural practices needs to be trained with the help of the concerned department. Thirdly, awareness, workshop and capacity building to understand the various aspects of coping with climate variability. Fourthly, modern application and communication tools related to climate variability and change must utilized appropriately, for timely and proper dissemination of climate related information.

\begin{tabular}{|c|c|c|c|c|}
\hline Sample village & Khekman & Tentha & Shirui & Hungpung \\
\hline $\begin{array}{c}\text { Agriculture \& } \\
\text { Allied sector }\end{array}$ & $\begin{array}{l}\text { Rice, Pulses, Seasonal Vegetables, Maize } \\
\text { etc. }\end{array}$ & $\begin{array}{l}\text { Rice, Pulses, Seasonal Vegeta- } \\
\text { bles, Maize etc. }\end{array}$ & $\begin{array}{l}\text { Rice, Pulses, } \\
\text { Seasonal Vegetables, } \\
\text { Fruits, maize, Spices etc. }\end{array}$ & $\begin{array}{l}\text { Rice, Pulses, Seasonal Vegetables, } \\
\text { Maize, Fruits, Spices etc. }\end{array}$ \\
\hline Livestock & $\begin{array}{l}\text { Chicken, Cow, Duck, } \\
\text { Pisciculture, Piggery }\end{array}$ & $\begin{array}{l}\text { Heifer, Cow, Poultry, Duckery, } \\
\text { Pisciculture, Piggery }\end{array}$ & $\begin{array}{l}\text { Buffalo, Cow, } \\
\text { Chicken, Fishery, } \\
\text { Pisciculture, Piggery }\end{array}$ & $\begin{array}{l}\text { Bull, Cow, } \\
\text { Poultry, Pisciculture, } \\
\text { Piggery }\end{array}$ \\
\hline Health & Khekman Primary Health Sub-Centre & $\begin{array}{l}\text { Tentha Primary Health Sub } \\
\text { Centre }\end{array}$ & Primary Health Sub Centre, ASHA & $\begin{array}{l}\text { Primary Health Sub Centre, ASHA, } \\
\text { District Hospital }\end{array}$ \\
\hline $\begin{array}{l}\text { Drinking water } \\
\text { source }\end{array}$ & Thoubal Turel (River) & $\begin{array}{l}\text { Tentha Pukhri Achouba } \\
\text { (Ponds) Wangjing River }\end{array}$ & $\begin{array}{l}\text { Shinguira Kong,Kokthi Kong, Yangui Kong } \\
\text { (River) }\end{array}$ & $\begin{array}{l}\text { Kazora, Mayora, Kaphungra, Kongr- } \\
\text { ara, Kazora (Ponds) }\end{array}$ \\
\hline Forest & Non-Wood Forest Products & Non-Wood Forest Products & Non-Wood Forest Products & Non-Wood Forest Products \\
\hline
\end{tabular}

Table 4: Questionnaire methods. 
Fifthly, policies need to be framed, keeping importance on challenges posed by the changing climate. Lastly, the above suggestions will help in formulating positive strategies for coping up climate variability, especially in socio economic, livestock, forests, spring shed, which contributes to more than $60 \%$ of livelihoods (rural population) in the State of Manipur.

\section{Some of the programme organised during the study}

1. Development of capacity building toward self-generation of agricultural organic inputs and its management practices:

1.1 Preparation of vermin-compost to improve economic condition.

1.2 Management of kitchen waste for better environment.

2. Started methods of ICM (Integrated Crop Management) as pilot for convergence.

2.1 Farmers Interest Group (FIG) has been formed and started ICM method on their own at 4 (four) selected villages of the project site.

2.2 Sharing of knowledge among farmers.

3. Encouragement of crop rotation to increase soil health for better sustainable agricultural practices.

3.1 Preparation for analysis of soil health

3.2 Rabi crop cultivation started to improve soil quality.

4. Enhancement of Knowledge for safe and better livelihood.

4.1 Organised extension programme on capacity building development in the neighboring villages.

4.2 Construction of climate resilient model housing and community shelter home.

5. Paddy cum fish culture has been practising in Nungsangkhong, Hungpung village, Ukhrul District.

\section{Acknowledgment}

Authors are very much thankful to the National Mission on Himalayan Studies, G.B Pant National Institute of Himalayan Environment and Sustainable Development, Ministry of Environment, Forests and Climate Change, Government of India for providing financial assistance to carry out this research work. The authors are thankful to the Director, Directorate of Environment and Climate Change, Government of Manipur for his time-to-time valuable support and cooperation during implementation of the research project.

\section{References}

1. Houghton J, Ding Y, Griggs D, Noguer M, van der Linden (2001) Climate change. Cambridge University Press, The scientific basis Cambridge, UK.

2. Hewitt K (1997) Regions of risk: A geographical introduction to disasters. London: Addison Wesley Longman, US.

3. Inter-governmental Panel for Climate Change (2014) Climate change 2014: impacts, adaptation, and vulnerability - IPCC WGII AR5 summary for policymakers. In: Field CB, Barros VR, Dokken DJ, Mach KJ, Mastrandrea MD, et al. (eds.). Inter-governmental Panel for Climate Change (1st edn.). Contribution of working group II to the fifth assessment report of the intergovernmental panel on climate change, Cambridge University Press, Cambridge and New York, UK. Pg no: 113.

4. Karl TR, Melillo JM, Peterson TC (2009) Global climate change impacts in the United States. ( $1^{\text {st }}$ edn). Cambridge University Press, Cambridge.

5. Forest survey of India report (2019)

6. Manipur Census (2011)

7. Ravindranath NH, Rao S, Sharma N, Nair M, Gopalakrishnan R, et al. (2011) Climate change vulnerability profiles for North East India. Current Science $101: 354-361$.

8. Pimentel D, Stachow U, Takacs DA, Brubaker DW (1992) Conserving biological diversity in agricultural/forestry systems. Bio-Science 42: 354362

9. Butt TA, McCarl BA, Kergna AO (2006) Policies for reducing agricultural sector vulnerability to climate change in Mali. Climate Policy 5: 583-598

10. Reilly J, Schimmelpfennig D (1999) Agricultural impact assessment vulnerability, and the scope for adaptation. Climatic Change 43: 745-788

11. Challinor A, Wheeler T, Garforth C, Craufurd P, Kassam A (2007) Assessing the vulnerability of food crop systems in Africa to climate change. Climatic Change 83: 381-399

12. Parry M, Carter TR (1998) Climate impact assessment and adaptation assessment. Earthscan, London, UK

13. Met Office (2011) Climate Observations, projections and impacts, Mexico. Exeter, Met Office, United Kingdom. 


\section{di}

Advances In Industrial Biotechnology | ISSN: 2639-5665

Advances In Microbiology Research | ISSN: 2689-694X

Archives Of Surgery And Surgical Education | ISSN: 2689-3126

Archives Of Urology

Archives Of Zoological Studies | ISSN: 2640-7779

Current Trends Medical And Biological Engineering

International Journal Of Case Reports And Therapeutic Studies | ISSN: 2689-310X

Journal Of Addiction \& Addictive Disorders | ISSN: 2578-7276

Journal Of Agronomy \& Agricultural Science | ISSN: 2689-8292

Journal Of AIDS Clinical Research \& STDs | ISSN: 2572-7370

Journal Of Alcoholism Drug Abuse \& Substance Dependence | ISSN: 2572-9594

Journal Of Allergy Disorders \& Therapy | ISSN: 2470-749X

Journal Of Alternative Complementary \& Integrative Medicine | ISSN: 2470-7562

Journal Of Alzheimers \& Neurodegenerative Diseases | ISSN: 2572-9608

Journal Of Anesthesia \& Clinical Care | ISSN: 2378-8879

Journal Of Angiology \& Vascular Surgery | ISSN: 2572-7397

Journal Of Animal Research \& Veterinary Science | ISSN: 2639-3751

Journal Of Aquaculture \& Fisheries | ISSN: 2576-5523

Journal Of Atmospheric \& Earth Sciences | ISSN: 2689-8780

Journal Of Biotech Research \& Biochemistry

Journal Of Brain \& Neuroscience Research

Journal Of Cancer Biology \& Treatment | ISSN: 2470-7546

Journal Of Cardiology Study \& Research | ISSN: 2640-768X

Journal Of Cell Biology \& Cell Metabolism | ISSN: 2381-1943

Journal Of Clinical Dermatology \& Therapy | ISSN: 2378-8771

Journal Of Clinical Immunology \& Immunotherapy | ISSN: 2378-8844

Journal Of Clinical Studies \& Medical Case Reports | ISSN: 2378-8801

Journal Of Community Medicine \& Public Health Care | ISSN: 2381-1978

Journal Of Cytology \& Tissue Biology | ISSN: 2378-9107

Journal Of Dairy Research \& Technology | ISSN: 2688-9315

Journal Of Dentistry Oral Health \& Cosmesis | ISSN: 2473-6783

Journal Of Diabetes \& Metabolic Disorders | ISSN: 2381-201X

Journal Of Emergency Medicine Trauma \& Surgical Care | ISSN: 2378-8798

Journal Of Environmental Science Current Research | ISSN: 2643-5020

Journal Of Food Science \& Nutrition | ISSN: 2470-1076

Journal Of Forensic Legal \& Investigative Sciences | ISSN: 2473-733X

Journal Of Gastroenterology \& Hepatology Research | ISSN: 2574-2566
Journal Of Genetics \& Genomic Sciences | ISSN: 2574-2485

Journal Of Gerontology \& Geriatric Medicine | ISSN: 2381-8662

Journal Of Hematology Blood Transfusion \& Disorders | ISSN: 2572-2999

Journal Of Hospice \& Palliative Medical Care

Journal Of Human Endocrinology | ISSN: 2572-9640

Journal Of Infectious \& Non Infectious Diseases | ISSN: 2381-8654

Journal Of Internal Medicine \& Primary Healthcare | ISSN: 2574-2493

Journal Of Light \& Laser Current Trends

Journal Of Medicine Study \& Research | ISSN: 2639-5657

Journal Of Modern Chemical Sciences

Journal Of Nanotechnology Nanomedicine \& Nanobiotechnology | ISSN: 2381-2044 Journal Of Neonatology \& Clinical Pediatrics | ISSN: 2378-878X

Journal Of Nephrology \& Renal Therapy | ISSN: 2473-7313

Journal Of Non Invasive Vascular Investigation | ISSN: 2572-7400

Journal Of Nuclear Medicine Radiology \& Radiation Therapy | ISSN: 2572-7419

Journal Of Obesity \& Weight Loss | ISSN: 2473-7372

Journal Of Ophthalmology \& Clinical Research | ISSN: 2378-8887

Journal Of Orthopedic Research \& Physiotherapy | ISSN: 2381-2052

Journal Of Otolaryngology Head \& Neck Surgery | ISSN: 2573-010X

Journal Of Pathology Clinical \& Medical Research

Journal Of Pharmacology Pharmaceutics \& Pharmacovigilance | ISSN: 2639-5649

Journal Of Physical Medicine Rehabilitation \& Disabilities | ISSN: 2381-8670

Journal Of Plant Science Current Research | ISSN: 2639-3743

Journal Of Practical \& Professional Nursing | ISSN: 2639-5681

Journal Of Protein Research \& Bioinformatics

Journal Of Psychiatry Depression \& Anxiety | ISSN: 2573-0150

Journal Of Pulmonary Medicine \& Respiratory Research | ISSN: 2573-0177

Journal Of Reproductive Medicine Gynaecology \& Obstetrics | ISSN: 2574-2574

Journal Of Stem Cells Research Development \& Therapy | ISSN: 2381-2060

Journal Of Surgery Current Trends \& Innovations | ISSN: 2578-7284

Journal Of Toxicology Current Research | ISSN: 2639-3735

Journal Of Translational Science And Research

Journal Of Vaccines Research \& Vaccination | ISSN: 2573-0193

Journal Of Virology \& Antivirals

Sports Medicine And Injury Care Journal | ISSN: 2689-8829

Trends In Anatomy \& Physiology | ISSN: 2640-7752

Submit Your Manuscript: https://www.heraldopenaccess.us/submit-manuscript 